\title{
Population morbidity in elderly lung cancer patients from Poland with specific trends in elderly women
}

\author{
Andrzej Śliwczyński ${ }^{1}$, Ewa Kalinka², Aleksandra Sierocka ${ }^{3}$, Petre Iltchev³ ${ }^{3}$ Dariusz Kowalski ${ }^{4}$, \\ Michał Marczak ${ }^{5}$ \\ ${ }^{1}$ National Health Fund, Poland \\ ${ }^{2}$ Department of Oncology, Polish Mother's Memorial Hospital - Research Institute, Lodz, Poland \\ ${ }^{3}$ Department of Health Care Policy, Medical University of Lodz, Lodz, Poland \\ ${ }^{4}$ Department of Lung Cancer and Chest Tumours, Maria Skłodowska-Curie Memorial Cancer Centre and Institute of Oncology, \\ Warsaw, Poland \\ ${ }^{5}$ Department of Management and Logistics in Health Care, Medical University of Lodz, Lodz, Poland
}

\begin{abstract}
Introduction: Lung cancer remains a leading cause of morbidity and mortality in Poland and globally. The objective of the study was to assess lung cancer incidence among elderly patients in Poland, including data for urban and rural populations, with trend analysis between 2008 and 2012.

Material and methods: Differences between lung cancer prevalence in the Polish population aged 65 years or older were assessed with respect to province, gender, and rural vs. urban areas during the 2008-2012 period. Data were extracted from the Polish National Health Authority and Statistical Bureau databases.

Results: Lung cancer morbidity among the elderly increased by $14.05 \%$ in urban areas but only by $4.01 \%$ in rural areas. A $22.41 \%$ overall increase was noted in the elderly female population, compared to a $7.29 \%$ increase among men aged 65 years and over. Regional differences in morbidity were observed.

Conclusions: The rationale behind the differences is likely to be multi-factorial. A change in risk factor exposure in the past is probably now being reflected in lung cancer morbidity. The difference between sexes can potentially be regarded as an unfortunate side-effect of increasing female empowerment. Urban vs. rural, as well as regional, variances are probably due to a multitude of factors, including differences in socio-economic status.
\end{abstract}

Key words: lung cancer, incidence, urban/rural, elderly patients.

\section{Introduction}

The epidemiological data regarding lung cancer in Poland broadly reflects the significant impact of the disease on population health observed in other parts of the developed world. Approximately 15,000 men and 5500 women in Poland are diagnosed with lung cancer every year, amounting to a standardised incidence rate (in 2008) of 52 men and 15 women per 100,000 inhabitants. According to the National Cancer Registry (NCR) [Krajowy Rejestr Nowotworów], lung cancer is the single largest contributor to cancer mortality, with a standardised mortality rate of 61.5 per 100,000 men and 15.5 per 100,000 women in 2008 [1, 2]. The average five-year survival rate oscillates around a dismal $14 \%$, albeit with substantial differences between clinical stages [3, 4]. Unfortunately, $60-70 \%$ of patients suf- fering from non-small cell lung cancer are diagnosed at a late unresectable or metastatic stage, which excludes radical therapy (surgical resection and/or radiochemotherapy) as a treatment option for many [5]. Relapses after radical treatment present as distant metastases in $25 \%$ of patients with initial stage IA and in $40 \%$ of patients with initial stage IB [6-8]. Analyses performed in 2011 based on data from the entire lung cancer patient population provided by the National Health Fund (NHF) [Narodowy Fundusz Zdrowia] between 2006 and 2009 [9] showed that $70 \%$ of patients were hospitalised, and $40 \%$ were treated by chemotherapy.

Tobacco smoking is a leading cause of premature mortality in Poland, exceeding the corresponding European values [10]. It results in the premature mortality of one in three males below 65 years of age in Poland. Premature tobacco-dependent deaths have been 
studied widely in the Polish population. These studies demonstrate that tobacco smoke exposure is the leading cause of cancer mortality and incidence, which is in line with findings from elsewhere in the world. Differences in prevalence among different sub-populations (e.g. rural vs. urban) can largely be explained by differential exposure to risk factors.

Previous studies based on data from a single institution showed that in the period between 2006 and 2007 there was no difference in clinical stage, histological type, tumour pathological grading, risk factor distribution, or overall survival between urban and rural patients with lung cancer [11]. We evaluated the differences in lung cancer incidence in the years 2008 to 2012 inclusive in elderly patients between urban and rural regions of Poland. We based our analysis on a more comprehensive dataset from reports submitted to regional divisions of the NHF, which is the major healthcare funding body in Poland.

\section{Material and methods}

In Poland, the NHF, in accordance with parliamentary legislation [9] and executive acts of the Minister of Heath $[9,12]$ generally finances healthcare. The treatment of lung cancer is reimbursed based on a contract between the NHF and specific hospitals or other healthcare providers. More details regarding the organisation and financing of public healthcare in Poland can be found in the regulations of the NHF [13-15].

Table 1. Comparison of incidence of lung cancer in patients aged 65 years and older from the years 2008-2012 between urban and rural regions of Poland. The differences between urban and rural areas for each year are statistically significant $(p<0.01)$

\begin{tabular}{llllll}
\hline Region & 2008 & 2009 & 2010 & 2011 & 2012 \\
\hline Urban & 1.047 & 1.093 & 1.081 & 1.114 & 1.189 \\
\hline Rural & 0.729 & 0.766 & 0.734 & 0.736 & 0.744 \\
\hline Poland & 0.925 & 0.967 & 0.946 & 0.966 & 1.015 \\
\hline
\end{tabular}

Table 2. Incidence of lung cancer in patients in Poland aged 65 years and older from the years 2008-2012 in urban and rural regions split by gender

\begin{tabular}{lccccc}
\hline $\begin{array}{l}\text { Gender/ } \\
\text { Region }\end{array}$ & 2008 & 2009 & 2010 & 2011 & 2012 \\
\hline Male & 1.348 & 1.387 & 1.347 & 1.360 & 1.403 \\
\hline Urban & 1.467 & 1.513 & 1.478 & 1.502 & 1.576 \\
\hline Rural & 1.161 & 1.196 & 1.149 & 1.149 & 1.147 \\
\hline Female & 0.531 & 0.574 & 0.601 & 0.597 & 0.650 \\
\hline Urban & 0.669 & 0.716 & 0.724 & 0.764 & 0.840 \\
\hline Rural & 0.302 & 0.339 & 0.323 & 0.325 & 0.342 \\
\hline
\end{tabular}

The lung cancer incidence data used for our analysis were taken from reports submitted by NHF provider institutions, covering nearly $100 \%$ of the Polish population. Information about patients of 65 years of age and above was extracted from the NHF system if their main diagnosis in the financial report to the NHF was C34.X (malignant neoplasm of the bronchus or lung according to the International Classification of Diseases [ICD-10]). Data were collected from the NHF database using Structured Query Language (SQL) tools with filters focused on age 65 years or older and an ICD-10 C34.X diagnosis.

Based on individual reports (identified by Polish national personal identification number PESEL) and their corresponding ICD-10 diagnoses, we were able to sub-divide our data set into age, gender, province (also "voivodeship" - województwo), and urban vs. rural categories.

The analysis was performed using Excel and Statistica 10 tools. Demographic data were extracted from the Main Statistic Authority database [16]. The statistical significance of differences between urban and rural populations was assessed using unpaired Student's $t$-tests, and Satterthwaite approximate $t$-tests. Differences between the two tests were assessed using the Folded $F$ statistic, to identify unequal variances between compared groups.

\section{Results}

The number of lung cancer patients aged 65 years or older in Poland increased between 2008 and 2012 by $14.05 \%$ in urban areas, and by $4.01 \%$ in rural areas (Table 1). Furthermore, a difference between the genders was observed in both urban and rural areas. In urban areas, the number of women aged 65 years or older suffering from lung cancer increased by $22.41 \%$, while for men the increase amounted to only $7.29 \%$. In rural areas, an equally stark gender difference was observed, with the number of lung cancer patients aged 65 years or older increased by $13.24 \%$ in the female population, while men experienced a decrease in prevalence of $1.2 \%$. (Table 2).

Regional differences in incidence rates were also observed (Table 3). In urban areas, the greatest increase in the number of patients aged 65 years or older with a diagnosis of lung cancer was observed in the northwestern part of Poland, comprising the following provinces: Greater Poland (24.67\%), Pomerania (22.44\%), Lodz (21.54\%), West Pomerania (20.99\%), and Lubusz (20.00\%) (Table 3). Similarly, in rural areas the increase in lung cancer prevalence among patients aged 65 years or older also differed between provinces. The greatest increase was again noted in the northwestern part of the country, in the following provinces: Lubusz (16.14\%), Greater Poland (13.65\%), and Pomerania 
Table 3. Incidence of lung cancer in population of 65 years and older in rural and urban parts of all provinces in Poland (original names in brackets)

\begin{tabular}{|c|c|c|c|c|c|}
\hline Region/Province & 2008 & 2009 & 2010 & 2011 & 2012 \\
\hline \multicolumn{6}{|l|}{ Urban } \\
\hline Lower Silesian (Dolnośląskie) & 0.986 & 1.092 & 1.018 & 1.014 & 1.082 \\
\hline Kuyavia-Pomerania (Kujawsko-Pomorskie) & 1.179 & 1.233 & 1.203 & 1.165 & 1.238 \\
\hline Lublin (Lubelskie) & 0.844 & 0.806 & 0.817 & 0.833 & 0.865 \\
\hline Lubusz (Lubuskie) & 0.832 & 0.932 & 0.934 & 0.937 & 0.990 \\
\hline Lodz (tódzkie) & 1.076 & 1.184 & 1.162 & 1.226 & 1.327 \\
\hline Lesser Poland (Małopolskie) & 1.057 & 1.037 & 1.049 & 1.073 & 1.139 \\
\hline Masovia (Mazowieckie) & 1.211 & 1.273 & 1.284 & 1.320 & 1.393 \\
\hline Opole (Opolskie) & 0.796 & 0.836 & 0.823 & 0.905 & 0.899 \\
\hline Subcarpathia (Podkarpackie) & 0.700 & 0.754 & 0.703 & 0.694 & 0.755 \\
\hline Podlachia (Podlaskie) & 0.772 & 0.828 & 0.833 & 0.855 & 0.869 \\
\hline Pomerania (Pomorskie) & 1.308 & 1.406 & 1.329 & 1.369 & 1.576 \\
\hline Silesian (Śląskie) & 0.991 & 0.977 & 0.978 & 1.041 & 1.084 \\
\hline Świętokrzyskie (Świętokrzyskie) & 1.062 & 1.194 & 1.084 & 1.138 & 1.133 \\
\hline Warmia-Mazuria (Warmińsko-Mazurskie) & 1.073 & 1.034 & 1.055 & 1.055 & 1.168 \\
\hline Greater Poland (Wielkopolskie) & 0.917 & 0.970 & 0.983 & 1.058 & 1.137 \\
\hline West Pomerania (Zachodniopomorskie) & 1.350 & 1.409 & 1.443 & 1.471 & 1.604 \\
\hline \multicolumn{6}{|l|}{ Rural } \\
\hline Lower Silesia (Dolnośląskie) & 0.639 & 0.716 & 0.622 & 0.582 & 0.660 \\
\hline Kuyavia-Pomerania (Kujawsko-Pomorskie) & 0.887 & 0.940 & 0.893 & 0.872 & 0.833 \\
\hline Lublin (Lubelskie) & 0.790 & 0.806 & 0.803 & 0.766 & 0.717 \\
\hline Lubusz (Lubuskie) & 0.694 & 0.784 & 0.741 & 0.782 & 0.788 \\
\hline Lodz (Łódzkie) & 0.673 & 0.727 & 0.762 & 0.780 & 0.760 \\
\hline Lesser Poland (Małopolskie) & 0.643 & 0.680 & 0.638 & 0.693 & 0.691 \\
\hline Masovia (Mazowieckie) & 0.802 & 0.838 & 0.810 & 0.822 & 0.806 \\
\hline Opole (Opolskie) & 0.629 & 0.700 & 0.623 & 0.656 & 0.645 \\
\hline Subcarpathia (Podkarpackie) & 0.600 & 0.609 & 0.569 & 0.555 & 0.573 \\
\hline Podlachia (Podlaskie) & 0.829 & 0.901 & 0.860 & 0.807 & 0.774 \\
\hline Pomerania (Pomorskie) & 0.790 & 0.824 & 0.777 & 0.799 & 0.842 \\
\hline Silesia (Śląskie) & 0.710 & 0.724 & 0.669 & 0.698 & 0.735 \\
\hline Świętokrzyskie (Świętokrzyskie) & 0.831 & 0.908 & 0.858 & 0.810 & 0.848 \\
\hline Warmia-Mazuria (Warmińsko-Mazurskie) & 0.919 & 0.922 & 0.906 & 0.830 & 0.915 \\
\hline Greater Poland (Wielkopolskie) & 0.627 & 0.676 & 0.654 & 0.688 & 0.690 \\
\hline West Pomerania (Zachodniopomorskie) & 0.847 & 0.765 & 0.810 & 0.784 & 0.842 \\
\hline
\end{tabular}

(12.41\%). Conversely, in some parts of eastern Poland a decrease was noted, namely in the following provinces: Lublin (8.65\%), Podlachia (7.51\%), Subcarpathia (3.89\%), and Kuyavia-Pomerania (3.48\%).

\section{Discussion}

In addition to demonstrating a universal increase in the prevalence of lung cancer in the Polish population aged 65 years or older between 2008 and 2012, our analysis permitted us to make several other general observations. Firstly, the increase in cancer incidence was more marked in urban than in rural populations (14.05\% and
$4.01 \%$, respectively). Secondly, in both urban and rural populations the change was more prominent in females compared to males, with males from rural regions experiencing a decrease in prevalence (urban $22.41 \%$ and $7.29 \%$, respectively; rural $13.24 \%$ and $-1.2 \%$, respectively). Finally, regional variations in lung cancer incidence were observed throughout the country, with the northwestern provinces showing the most marked increase, and the eastern provinces only modest increases or even decreases in incidence in the rural population.

The causes of the recent universal increase are likely to be multi-factorial and are unlikely to be explicable by one overarching hypothesis. We shall thus discuss 
in turn the likely contributing factors. A change in risk factor exposure would be the most elegant explanation for the observed changes in lung cancer in the population aged 65 years or older. Of all the risk factors for lung cancer, smoking clearly emerges as the leading preventable cause. Changes in smoking patterns would accordingly explain the increase in lung cancer prevalence. The difference in incidence between genders particularly lends itself to this explanation because, while the prevalence of smoking has been decreasing in men, in women it seems to be increasing relatively. One hypothesis explaining this increase in female smokers is that of gender empowerment [17]. The Gender Empowerment Measure (GEM) is a quantitative measure of gender equality, and it appears to be an excellent predictor of the female-to-male smoking ratio worldwide. Countries with very high GEMs (e.g. Sweden) also have approximately equal tobacco consumption among men and women, while a low GEM predicts relatively low female tobacco consumption (e.g. Bangladesh).

One should remember, however, that changes in tobacco consumption are only reflected in lung-cancer incidence data after a period of latency, which is estimated to be in the range of 30 years [18]. Any changes we observe now are thus likely to be effects of past changes in health behaviour, provided we accept the risk factor hypothesis. It is quite apparent that such past data would be exceedingly difficult to obtain and analyse, and thus the hope of finding an accurate correspondence between past behaviour and current incidence remains futile. Nevertheless, there is circumstantial evidence from other countries supporting our hypothesis. Wiencke et al. showed that in the German population the number of diagnosed cancers attributable to smoking rose between 1999 and 2008 both in men and women. Moreover, the authors point to the fact that the prevalence of smoking in women was on the increase until recently, which is likely to result in an increase in lung cancer mortality in the future [19].

The urban vs. rural, as well as regional, differences may reflect variances in socio-economic status. It is known that socio-economically disadvantaged populations have a higher rate of tobacco consumption and are more susceptible to its deleterious effects on health, partly due to lack of support structures [20]. While the available data does not permit us to deduce how exactly socio-economic factors may have contributed to tobacco consumption patterns, a few hypotheses can be drawn up. Firstly, political changes in Poland in the late 1980s and early 1990s are known to have led to an increase in socioeconomic inequality across the entire country. If this led to a higher uptake of tobacco in the disadvantaged population, any resulting pathological sequelae could be starting to emerge in the data we have analysed.
Whilst important, smoking is not the only risk factor for lung cancer. Cancer Research UK quotes multiple environmental hazards as contributors to disease incidence, including but not limited to, engine emissions, household fuel combustion, and occupational exposure (roofing, hematite mining, chromium, cobalt, and many others). A change in exposure pattern to these risk factors could be partly responsible for the observed results but is unlikely to be of great importance when compared to smoking.

Published data show that the highest mortality incidence ratio for lung cancer was for medium human development countries. Linear regression analysis showed a reverse significant relationship between mortality incidence ratio and human development index [21].

Moreover, a later analysis based on GLOBOCAN data showed that the country-specific Human Development Index was strongly correlated with age-standardised incidence $(r=0.70)$ and mortality $(r=0.67)$, and to a lesser extent gross domestic product (GDP) $(r=0.24$ to 0.55). Among men, 22 and 30 (out of 38 and 36) countries showed declining incidence and mortality trends, respectively, whilst among women, 19 and 16 countries showed increasing incidence and mortality trends, respectively. Among men, the average annual percentage changes ranged from -2.8 to -0.6 (incidence) and from -3.6 to -1.1 (mortality) in countries with declining trend, whereas among women the average annual percentage change range was from 0.4 to 8.9 (incidence) and from 1 to 4.4 (mortality) in countries with increasing trends. Thus, lower income in rural vs. urban area could be one of the factors influencing increasing lung cancer incidence in Poland in rural areas, when the trend among women in the analysed population in our study complies with the global findings.

Finally, one has to consider potential artefactual effects on the dataset, due to confounding or bias. The accuracy of the analysis relies on the premise of complete coverage of the population by the dataset. It is however conceivable that this coverage may have improved over the period analysed, leading to higher uptake of health services by the population, thus leading to an apparent increase in prevalence.

\section{Conclusions}

In summary, the authors conclude that the increase in lung cancer incidence observed in Poland between 2008 and 2012, particularly in the female population, might be due to past changes in tobacco consumption. Efforts to curb smoking should thus be maintained, with particular focus on the sub-populations most likely to exhibit an increase in the habit. 


\section{Disclosure}

The authors report no conflict of interest.

\section{References}

1. Wojciechowska U, Didkowska J, Zatoński W. Nowotwory złośliwe w Polsce w 2008 r. [Malignant neoplasms in Poland in 2008]. Centrum Onkologii - Instytut M. Skłodowskiej-Curie, Warszawa 2010.

2. Szczuka I, Roszkowski-Sliz K. Lung cancer in Poland in 1970-2004. Pneumonol Alergol Pol 2008; 76: 19-28.

3. Sobin LH, Gospodarowicz MK, Wittekind C. TNM Classification of Malig nant Tumours, $7^{\text {th }}$ ed. Wiley-Blackwell, Oxford 2009.

4. Wojciechowska U, Didkowska J, Zatoński W. Wskaźnik przeżyć chorych na nowotwory złośliwe w Polsce zdiagnozowanych w latach 2000-2002 [Survival of malignant neoplasms patients diagnosed between 2000 and 2002 in Poland]. Centrum Onkologii - Instytut M. SkłodowskiejCurie, Warszawa 2009.

5. Chansky K, Sculier J, Crowley JJ, et al. The International Association for the Study of Lung Cancer Staging Project: prognostic factors and pathologic TNM stage in surgically managed non - small cell lung cancer. J Thorac Oncol 2009; 4: 792-801.

6. Port JL, Kent MS, Korst RJ, et al. Tumor size predicts survival within stage IA non-small cell lung cancer. Chest 2003; 124: 1828-1833.

7. Voltolini L, Rapicetta C, Luzzi L, et al. Pattern of recurrence and survival of c-la NSCLC diagnosed by transpleural methods. I Cardiovasc Surg (Torino) 2008; 49: 697-702.

8. Deslauriers J, Gregoire J. Surgical therapy of early non-small cell lung cancer. Chest 2000; 117 (4 Suppl 1): 104S-109S.

9. Rozporządzenie Ministra Zdrowia z dnia 11.01.2010 r. zmieniające rozporządzenie w sprawie świadczeń gwarantowanych z zakresu programów zdrowotnych [Decree of the Minister of Health from $11 / 01 / 2010$ amending the decree regarding guaranteed services within health programs] (Dz.U. [Journal of Laws] 2010, No 05, item 29, as amended).

10. World Health Organization (WHO). The current status of the tobacco epidemic in Poland. WHO, Copenhagen 2009.

11. Rybojad P, Dłuski D, Rybojad B. Urban vs. rural patients. Differences in stage and overall survival among patients treated surgically for lung cancer. Ann Agric Environ Med 2013; 20: 101-105.

12. Rozporządzenie Ministra Zdrowia z dnia 02.03.2010 r. zmieniające rozporządzenie w sprawie świadczeń gwarantowanych z zakresu leczenia szpitalnego [Decree of the Minister of Health from 02/03/2010 amending the decree regarding guaranteed services within hospital treatment] (Dz.U. [Journal of Laws] 2010, N0 30, item 157, as amended).

13. Zarządzenie nr 101/2007/DGL 05.11.2007 r. zmieniające zarządzenie w sprawie przyjęcia „Szczegółowych materiałów informacyjnych o przedmiocie postępowania w sprawie zawarcia umów o udzielanie świadczeń opieki zdrowotnej oraz o realizacji i finansowaniu umów o udzielanie świadczeń opieki zdrowotnej w rodzaju: leczenie szpitalne". [Ordinance No. 101/2007/DGL from 05/11/2007 amending the ordinance regarding the adoption of 'Detailed information materials on the subject of proceedings regarding the conclusion of contracts of provision of hospital treatment health care services'].

14. Zarządzenie nr 36/2008/DGL Prezesa NFZ z dnia 19.06.2008 r. w sprawie określenia warunków zawierania i realizacji umów w rodzaju leczenie szpitalne w zakresie terapeutyczne programy zdrowotne [Ordinance No. 36/2008/DGL of the President of the National Health fund from 19/06/2008 regarding the determination of conditions of conclusion and execution of contracts of hospital treatment provision, within the domain of therapeutic health programs].

15. Zarządzenie $\mathrm{nr}$ 65/2009/DGL Prezesa NFZ z dnia 19.06.2008 r. w sprawie określenia warunków zawierania i realizacji umów w rodzaju leczenie szpitalne w zakresie terapeutyczne programy zdrowotne [Ordinance No. 36/2008/DGL of the President of the National Health fund from 19/06/2008 regarding the determination of conditions of conclusion and execution of contracts of hospital treatment provision, within the domain of therapeutic health programs].

16. https://stat.gov.pl/banki-i-bazy-danych/
17. Hitchman SC, Fong GT. Gender empowerment and female-to-male smoking prevalence ratios. Bull World Health Organ 2011; 89: 195-202.

18. Weiss W. Cigarette smoking and lung cancer trends. A light at the end of the tunnel? Chest 1997; 111: 1414-1416.

19. Wienecke A, Barnes B, Lampert T, et al. Changes in cancer incidence attributable to tobacco smoking in Germany, 1999-2008. Int J Cancer 2014; 134: 682-691.

20. Hiscock R, Bauld L, Amos A, et al. Socioeconomic status and smoking: a review. Ann N Y Acad Sci 2012; 1248: 107-123.

21. Rafiemanesh H, Mehtarpour M, Khani F, et al. Epidemiology, incidence and mortality of lung cancer and their relationship with the development index in the world. J Thorac Dis 2016; 8: 1094-1102.

22. Wong MCS, Lao XQ, Ho KF, et al. Incidence and mortality of lung cancer: global trends and association with socioeconomic status. Sci Rep 2017; 7: 14300 . 